\title{
Criminology Study of Crime of Fencing the Stolen Goods
}

\author{
Supriyono ${ }^{1}$
}

Abstract: Criminal offense is regulated in Article 480 of the Criminal Code, Article 481 and 482 of the Criminal Code. Criminal detention is an act that is prohibited by law, because detention is obtained from crime. Criminology perspective plays an important role in studying fencing acts as a form of criminal action by looking at the elements inherent in criminal acts of detention. The formulation of the problem in this research is how Criminology review in the criminal act of holding stolen goods? In this study the authors used a normative juridical method with research specifications in the form of descriptive analysis. The data used for this research are primary and secondary data taken by field observation, interviews, and literature study. Based on the research, it can be concluded that the criminology point of view shows legal efforts for the crime in the form of composing legislation (criminalization process) in the form of legal products in the laws governing criminal offenses stipulated in Criminal Code Article 480-482, in the scope of criminology as criminal etiology in criminal offenses namely internal and external factors.

Keywords: Criminology; Criminal Offense; Stolen Goods.

\section{Introduction}

The $4^{\text {th }}$ paragraph of the Preamble of the 1945 Constitution which is the constitutional basis of the country states that one of the objectives of the state is to create public welfare and to educate the nation's life. This has the implication that public welfare becomes a constitutional ideal, accompanied by the growth of an intelligent Indonesian society and able to deliver the Indonesian nation as a sovereign and prosperous nation. So all efforts and development carried out by this country must lead to this goal so as to create people's welfare. In community relations there are a variety of relationships between community members, namely relationships arising from the interests of members of the community. The diversity of these relationships, One of the laws that plays an important role in regulating human interaction is the Criminal Law. Criminal law is all of the commands and prohibitions imposed by the state and which are threatened with a misdemeanor (criminal) who does not obey them, all the rules for establishing (complying with) and carrying out the crime. ${ }^{2}$ Criminal Law as a public law aims to regulate community interaction in accordance with the law itself. In relation to public regulation, especially regarding norms of prohibition that must have sanctions, negative then the criminal law takes the position as an effective solution to overcome the above problems. With the existence of the criminal law is expected to provide a sense of security in society both to individuals and groups in carrying out their daily activities.

The law has become a Commander who sets what can and should not be done. The goal of law is not only to provide criminal sanctions against people who have

\footnotetext{
${ }^{1}$ Student of Master of Law, Universitas Islam Sultan Agung Semarang and Indonesian Police, email: supriyonoblora@gmail.com

${ }^{2}$ Moeljatno, 1982, Azas-azas Hukum Pidana, Jakarta: PT. Bina Aksara, p.7
} 
committed illegal acts that might occur, the law always strives to guarantee and protect the rights of individuals and society and protect the interests of the State. Crimes will not go away on their own, instead crime cases are increasingly common and the most dominant is the type of crime against assets, especially those which include criminal offenses.

The law occupies the most urgent position to overcome the existence of this crime problem. Legal instruments are needed to resolve conflicts or crimes that exist in society. One of the efforts to prevent and control crime is to use criminal law with criminal sanctions. ${ }^{3}$

Crime can be interpreted criminological and juridical. Crime in the criminological sense is human action that tarnishes the basic norms of society. This is intended as an elemental act that violates the rules that live and develop in society. Juridical crime that is a crime or an evil act in the sense of criminal law means that the crime was formulated in criminal regulations. The most common criminal problem occurring in society is the crime of property (material crime), such as theft, extortion, embezzlement, fraud, vandalism, and detention. One of the criminal acts against assets that still often causes debate is the criminal act of detention originating from the results of theft.

Criminal offense is regulated in Article 480 of the Criminal Code, Article 481 and 482 of the Criminal Code. Criminal detention is an act that is prohibited by law, because detention is obtained from a crime, can be said to help or facilitate a criminal act. committing a crime because the crime goods were obtained from the proceeds of crime as well and the detention here is the second perpetrator in the matter of its implementation, then the authorities must prove in advance whether a person is able to be accounted for in other words the element of error and intentionality. ${ }^{4}$

With this detention, specific criminal acts against property can increase and develop, even with the detention of people who originally did not want to commit crimes, but with the presence of detention arises the desire for someone to sell, rent, exchange, pawn the goods to collectors and obtain profits even though the way this is done is against the law. With the nanny it will make it easier for people who commit crimes where the nanny helps to channel objects that are the result of crime or help perpetrators of crimes to gain an advantage over objects that are the result of a crime committed.

Based on the aforementioned background, the following problems are formulated: How Criminology review in the criminal act of holding stolen goods?

\section{Research Methods}

To conduct a study in this study the authors use the normative juridical method. This approach is also known as the literature approach, namely by studying books, legislation and other documents related to this research. The specifications in this study are descriptive analysis. The data used for this study are primary and secondary

\footnotetext{
${ }^{3}$ Hari Saherodji, 1980, Pokok-Pokok Kriminologi, Jakarta: Aksara Baru, p.20

${ }^{4}$ Sholehudin, 2004, Sistem Sanksi Dalam Hukum Pidana (Ide Dasar Doule Tracj Sistem dan Implementasinya), Jakarta: PT Raja Grafindo Persada, p.71.
} 
data. Primary data is data obtained directly from the field or from the first source and has not been processed by other parties. Then secondary data is data obtained from library research. The data used was collected through the stages of field observation, interviews, and literature study.

\section{Results and Discussion}

The whole science which deals with matters related to the crime of each other which had been separate data was combined into a systemic roundness called criminology. This is why people say criminology is a combination of science that discusses crime. Thorsten Sellin states that criminology is a king without a country. ${ }^{5}$ The benefit of learning criminology is that criminology contributes to the drafting of new legislation (criminalization process), explaining the causes of crime (criminal etiology) which in turn creates efforts to prevent crime.

Sutherland revealed about crime, according to him crime means a behavior that is prohibited by the State because it is detrimental to him, the State reacts with punishment in an effort to prevent and eradicate it. ${ }^{6}$ Wolfgang divides criminology as an act called a crime, a criminal, and a reaction that is shown both to the act and to the culprit. $^{7}$

Criminology contributes in the preparation of new legislation (criminalization process), explaining the causes of crime (criminal etiology) which in turn creates efforts to prevent crime (criminal prevention). ${ }^{8}$ Criminology has undeniably brought countless benefits in reducing human suffering, and this is the main goal of studying criminology. In this case, criminal offense as a concentration of authors in research in terms of criminology. Criminal offense has been regulated in Chapter XXX of Book II of the Criminal Code as a criminal offense. According to Prof. Satochid Kartanegara, the criminal act of detention is a criminal offense, that is, because the act of holding has pushed other people to commit crimes that they might not have committed, if no one was willing to accept the proceeds of crime. ${ }^{9}$

Definition of retirement according to Article 480 of the Criminal Code:

- Anyone who buys, offers, exchanges, accepts pawn, receives as a gift, or because he wants to make a profit, sell, exchange, procure, carry, store or hide, rent an object, which is known or deservedly must be suspected of being obtained from a crime;

- Whoever benefits from the proceeds of an object, which he knows or deserves must be assumed that obtained from evil.

Criminal detention committed after the completion of a crime against wealth, namely regarding an item obtained from a crime is usually considered to facilitate or help the crime. Just as the perpetrators of the crime hope that the goods that have been stolen, confiscated, embezzled, or obtained by fraud, or accommodated by a host will make it difficult to investigate the relevant crime. Thus the perpetrators of the crime will easily

\footnotetext{
${ }^{5}$ Simandjuntak, B and Chaidir Ali, 1980, Cakrawala Baru Kriminologi, Bandung: Tarsito, p.9

${ }^{6}$ Yesmil Anwar, 2010, Kriminologi, Bandung: PT Refika Aditama, p. 179.

${ }^{7}$ Wahyu Muljono, 2012, Pengantar Teori Kriminologi, Yogyakarta: Pustaka Yustitia, p. 35

${ }^{8}$ Mulyana W. Kusumah, 1988, Kejahatan dan Penyimpangan, Jakarta: YLBHI, p. 3

${ }^{9}$ PAF Lamintang, Theo Lamintang, 2009, Delik-delik Khusus Kejahatan Terhadap Harta Kekayaan, Jakarta: Sinar Grafika, p.362
} 
repeat their actions to obtain goods by way of crime. This explains that the criminal offense in the criminal perspective shows legal remedies for the crime.

\subsection{Drafting legislation (criminalization process)}

In the process of criminalization in the form of created legal products, it can be seen in the legislation governing criminal offenses that are regulated in the Criminal Code in Articles 480-482 with the forms of detention are as follows:

- Detention in the principal form (Article 480 of the Criminal Code);

Article 480 of the Criminal Code is regulated as follows: With imprisonment of up to four years or a maximum fine of Rp. 900, - convicted : Because as an accomplice, whoever buys, rents, exchanges, accepts a pawning, receives a gift or gains a profit, keeps or hides an item, which he knows or is supposed to have obtained because of a crime; Anyone who takes advantage of the results of something, knows or deserves it must be assumed that it was obtained because of a crime. ${ }^{10}$

- Detention as a habit (Article 481 of the Criminal Code);

Article 481 of the Criminal Code as follows: Anyone who makes a habit of deliberately buying, exchanging, accepting pawning, storing or hiding objects, obtained because of a crime, is sentenced to prison for up to seven years; The wrongful person can be revoked of the rights mentioned in Article 35 No. 1-4 and can be fired from carrying out the work used to commit the crime (KUHP 35, 480, 486, 517). ${ }^{11}$ Minor arrest (Article 482 of the Indonesian Criminal Code);

- Article 482 of the Criminal Code is regulated as follows:

The act explained in Article 480 was sentenced as a light sentence, with a maximum imprisonment of three months or a maximum fine of $\mathrm{Rp} .900,-$, if the item was obtained because of one of the crimes, which are described in Articles 364, 373, $379 .^{12}$

\subsection{Causes of crime (criminal etiology)}

The factors that cause the occurrence of criminal acts against theft of the result are due to internal and external factors;

- Internal factors : Mental Factors or intelligence; Mental factors related to the level of intelligence. If someone has a good level of intelligence, then of course that person can easily adjust himself to the circumstances and development of society. But on the contrary if the level of intelligence is low then the person concerned is unable to find and find the best way and is no exception doing actions that deviate and contrary to applicable legal rules.

- External Factors: 1) Environmental factor: A person originally comes from a good offspring, if the social environment in the community where he lives is an environment where perpetrators of crime are not impossible then he too is carried away by committing crimes. One of the causes of a person committing a crime is the state of the environment in which that person is. Someone can be a criminal not only from a poor family, but also from a rich family. In general, people who commit

\footnotetext{
${ }^{10}$ R. Soesilo, 1996, Kitab Undang-Undang Hukum Pidana (KUHP) Serta Komentar-Komentar Lengkap Pasal Demi Pasal, Bogor: Politeia, p.314

11 Ibid, p.316

${ }^{12}$ Ibid.
} 
crimes come from a bad environment; 2) Economic factors: Another factor is the economy due to the difficulty of the economic situation that results in the lack of good jobs for people who are supposed to be workers, so that to meet their needs is very difficult, this causes a person to cut corners by committing theft. The same thing happens to people who carry out the detention, in order to make a big profit so that they take actions against the law. For those who do not have the provision of good education and skills, it is difficult to compete in getting a decent job. So eventually they become unemployed. As for survival without money and work, the easiest way to do this is to steal and then sell it to people who are willing to collect stolen goods.

\subsection{Efforts to prevent the occurrence of crime (criminal prevention)}

Based on the scope of the third criminology, namely efforts to prevent the occurrence of crime (criminal prevention) in criminal acts of detention in which efforts to prevent crime in the possession of stolen goods are used in the form of penalties indirectly become a reminder to the public that the act of holding stolen goods as a crime and the impact of criminal liability that must be faced when carrying out these actions.

The application of criminal law as one of the policies to prevent crime in the possession of stolen goods can be carried out starting from the stage of the investigation and prosecution (pre-adjudication stage) before the case is examined and tried in the judicial process. The giving of punishment to the perpetrators of the crime of the theft of the result of the theft by the judge in the Court is a deterrent and at the same time as a form of coaching for the offender so that the offender does not repeat his actions after the offender returns to the midst of the community.

This also correlates with theory in criminological theory where evil arises because of purely sociological or social psychological evil behavior is the influence of social structure, group pressure, social role, social status, or symbolic internalization which is wrong. Evil behavior is formed by a bad and evil environment, unattractive school conditions and relationships that are not directed by the values of decency and religion. This theory reveals that the cause of crime because it is influenced by environmental factors, both family, economic, social, cultural, defense and technological discoveries. This theory directs us that people have a tendency to commit crime because the process of imitating their surroundings or better known as the process of imitation. ${ }^{13}$

\section{Closing}

\subsection{Conclusions}

Criminal offense in a criminological point of view shows the legal remedies for the crime in the form of the first formulation of legislation (criminalization process), namely the process of criminalization in the form of created legal products seen in legislation governing criminal offenses regulated in the Criminal Code in Articles 480482 with forms of detention, the second in the scope of criminology as a criminal

\footnotetext{
${ }^{13}$ Ramadhan, Tinjauan Kriminologis Terhadap Kejahatan yang Terjadi di Wilayah Pertambangan Poboya, Journal of Legal Opinion, Issue 6 Vol.2, 2014, p.5
} 
etiology or causes of crime in the criminal offense, namely internal factors in the form of mental or intelligence factors, and external factors in the form of environment and economic factors, the third is efforts to prevent the occurrence of crimes (criminal prevention) in criminal acts of detention in which efforts to prevent crime in the possession of stolen goods are used in the form of indirect punishment as a reminder to the public that the act of holding stolen goods as a crime and the impact of criminal liability must be faced when carrying out these actions.

\subsection{Suggestions}

- For law enforcement officers, especially the police, the need for more optimal supervision and coordination of the crime of holding stolen goods so that this crime every year experiences a reduction rather than an increase;

- The community is expected to always be vigilant and suspicious, especially of used goods that are sold at prices that are very far from the market price, even more so if they are not equipped with a letter or memorandum of purchase because these items may be proceeds of crime. because criminal offense can be in any form.

\section{References}

\section{Book}

[1] Hari Saherodji, 1980, Pokok-Pokok Kriminologi, Jakarta: Aksara Baru

[2] Moeljatno, 1982, Azas-azas Hukum Pidana, Jakarta: PT. Bina Aksara

[3] Mulyana W. Kusumah, 1988, Kejahatan dan Penyimpangan, Jakarta: YLBHI

[4] PAF Lamintang, Theo Lamintang, 2009, Delik-delik Khusus Kejahatan Terhadap Harta Kekayaan, Jakarta: Sinar Grafika

[5] R. Soesilo, 1996, Kitab Undang-Undang Hukum Pidana (KUHP) Serta KomentarKomentar Lengkap Pasal Demi Pasal, Bogor: Politeia

[6] Sholehudin, 2004, Sistem Sanksi Dalam Hukum Pidana (Ide Dasar Doule Tracj Sistem dan Implementasinya), Jakarta: PT Raja Grafindo Persada

[7] Simandjuntak, B and Chaidir Ali, 1980, Cakrawala Baru Kriminologi, Bandung: Tarsito

[8] Wahyu Muljono, 2012, Pengantar Teori Kriminologi, Yogyakarta: Pustaka Yustitia

[9] Yesmil Anwar, 2010, Kriminologi, Bandung: PT Refika Aditama

\section{Regulations}

[1] The 1945 Constitution of the Republic of Indonesia

[2] Criminal Law Book

\section{Journal}

[1] Ramadhan, Tinjauan Kriminologis Terhadap Kejahatan yang Terjadi di Wilayah Pertambangan Poboya, Journal of Legal Opinion, Issue 6 Vol.2, 2014 